\title{
Retrospective Analysis of Gestational Trophoblastic Neoplasia: Single Center Experience
}

\author{
Veli SUNAR ${ }^{1}$, Vakkas KORKMAZ², Zafer ARIK³, Bulent OZDAL ${ }^{2}$, Yaprak ENGIN USTUN ${ }^{4}$ \\ ${ }^{1}$ University of Health Sciences, Zekai Tahir Burak Women's Health Training and Research Hospital, \\ Medical Oncology Clinic \\ ${ }^{2}$ University of Health Sciences, Zekai Tahir Burak Women's Health Training and Research Hospital, Gynecologic Oncology \\ ${ }^{3}$ Hacettepe University Cancer Institute, Department of Medical Oncology \\ ${ }^{4}$ University of Health Sciences, Zekai Tahir Burak Women's Health Training and Research Hospital, \\ Obstetrics and Gynecology Department, Ankara, TURKEY
}

\begin{abstract}
This study aims to analyze the clinicopathologic characteristics and treatment outcomes of our patients with gestational trophoblastic neoplasia (GTN) and to present our real-life experience. A total of 32 patients with GTN diagnosed according to the FIGO 2002 criteria followed in Zekai Tahir Burak Women's Health Training and Research Hospital between 2011-2018 were included. Demographic features, treatment outcomes, and survival were analyzed retrospectively. The median follow up time was 32.1 (3.3-76.9) months. Of the 32 patients, 27 (84.4\%) were defined as low-risk GTN (risk score < 7) and 5 (15.6\%) were high-risk GTN (risk score $\geq 7$ ) according to the FIGO risk score. Seventeen (62.9\%) patients with low-risk GTN achieved complete remission (CR) with single agent MTX. CR rate was 60\% (12/20) in patients receiving weekly MTX and $71.4 \%(5 / 7)$ in MTX-FA eight-day regimen ( $p=0.590)$. Of the 9 MTX resistant patients, 8 (88.8\%) achieved CR with second-line Actinomycin D (ActD). Three (60\%) out of the five high-risk GTN patients acquired CR with first-line EMA-CO (etoposide, MTX, plus ActD alternating with cyclophosphamide and vincristine). In the follow-up period one patient (3.1\%) had recurrent disease. By the data cut off date, all of the patients were alive and CR could not be achieved in one (3.1\%) patient. All patients with low-risk GTN achieved CR with sequential therapies ultimately. Therefore, single agent MTX is a reasonable option in the initial treatment of low-risk GTN. Moreover, Actinomycin D is highly effective in patients with low-risk GTN who are resistant to MTX.
\end{abstract}

Keywords: Gestational Trophoblastic Neoplasia, Methotrexate, Trophoblastic Disease, actinomycin D, EMA-CO protocol

ÖZET

\section{Gestasyonel Trofoblastik Neoplazi Hastalarının Retrospektif Analizi: Tek-Merkez Deneyimi}

Bu çalışmanın amacı Gestasyonel Trofoblastik Neoplazi (GTN) tanılı hastalarımızın klinikopatolojik özelliklerini ve tedavi yanıtlarını analiz ederek kendi hastalarımııın gerçek yaşam verilerini ortaya koymaktır. Çalışmaya 2011-2018 yılları arasında Zekai Tahir Burak Kadın Sağlığı ve Eğitim Araştırma Hastanesi'nde FIGO 2002 kriterlerine göre GTN tanısı almış 32 hasta dahil edildi. Hastaların demografik Özellikleri, tedavi modaliteleri, tedaviye yanıt oranları ve genel sağkalımları retrospektif olarak analiz edildi. Hastaların medyan takip süresi 32.1 ay (3.3-76.9) idi. Çalışmaya dahil edilen 32 hastadan 27 tanesi (\%84.4) FIGO risk skoruna göre düşük riskli iken (risk skoru < 7) 5 tanesi (\%15.6) yüksek riskliydi (risk skoru z 7). Düşük riskli GTN hastalarının \%62.9'da birinci sıra tedavide tek ajan Metotreksat (MTX) ile komplet remisyon elde edildi. Haftalık MTX tedavisi alan hastalarda komplet remisyon oranı \% 60 (12/20) iken MTX-FA 8-gün rejimi alan hastalarda komplet remisyon oranı \%71.4 (5/7) olarak saptandı ( $p=0.590)$. MTX dirençli 9 hastanın 8' inde (\%88.8) ikinci sıra Aktinomisin D ile komplet remisyon elde edildi. Yüksek riskli GTN tanıı 5 hastanın 3'ünde (\% 60) birinci sıra EMA-CO (etoposide, MTX ve ActD, siklofosfamid ve vinkristin ile sıralı) ile komplet remisyon elde edildi.

ORCIDS: Veli Sunar: 0000-0003-4672-4621 
International Journal of Hematology and Oncology

Takip süresince sadece 1 hastada (\%3.1) relaps saptandı. Data kesim tarihi itibariyle tüm hastalarımız hayatta olup sadece bir hastada (\%3.1) komplet remisyon elde edilemedi. Düşük riskli GTN hastalarında tek ajan MTX ile tedaviye başlamak akılcı bir yaklaşım olup nihayetinde hastaların tamamında sıralı tedavilerle komplet remisyon elde edildi. Ayrıca MTX dirençli düșük riskli GTN hastalarında Aktinomisin D oldukça etkin bir tedavidir.

Anahtar Kelimeler: Gestasyonel trofoblastik neoplazi, Metotreksat, Trofoblastik hastallik, Aktinomisin D, EMA-CO protokolü

\section{INTRODUCTION}

Gestational trophoblastic neoplasia (GTN) denotes a group of malignant neoplasms resulting from abnormal proliferation of the trophoblastic tissue. It consists of 4 histological types which include invasive mole, choriocarcinoma, placental site trophoblastic tumor (PSTT), and Epithelioid trophoblastic tumor (ETT). ${ }^{1}$ GTN may arise from premalign molar pregnancy (classified as partial hydatidiform moles (PHMs) or complete hydatidiform moles (CHMs), or a non-molar pregnancy. ${ }^{2}$ Approximately half of GTNs develop following a molar pregnancy while $25 \%$ develop after tubal pregnancy or miscarriages, and $25 \%$ follow term or preterm pregnancy. ${ }^{3,4}$ In the United Kingdom, the incidences of CHM and PHM were reported to be one and three in 1.000 pregnancies, respectively. While post-molar GTN develops in approximately 15 percent of patients following CHM, this rate is $0.5 \%-1 \%$ after PHM. ${ }^{5}$

In the past years when effective chemotherapy was lacking, the uterus-limited disease was usually cured by hysterectomy, while the metastatic disease was almost always fatal. ${ }^{6}$ Nowadays, there are many effective chemotherapeutic agents and cure is obtained in the majority of patients with right treatment strategies and patient's reproductive potential can be maintained. ${ }^{7}$

All patients diagnosed with GTN should be staged before treatment and the prognostic risk score should be determined. Patients are typically staged according to the combination of International Federation of Gynecology and Obstetrics (FIGO) anatomic staging system and prognostic risk scoring ${ }^{8}$ The prognostic risk score is used to estimate the risk of resistance to single-agent chemotherapy with either Methotrexate (MTX) or Actinomycin D (ActD). A score of 0-6 predicts low-risk of resistance to monotherapy whereas a score of $\geq 7$ suggests high-risk of resistance to single-agent thus requiring a combination chemotherapy. ${ }^{9-13}$
Patients with low risk GTN achieve survival rates up to $100 \%$ with monotherapy of MTX or ActD. ${ }^{14}$, ${ }^{15}$ MTX is usually the first-line agent of choice among available drugs with variable regimens. ${ }^{16-18}$ Multi-agent chemotherapy should be administered in the initial treatment of patients with high-risk GTN. ${ }^{19}$ The most commonly preferred first-line regimen is EMA-CO (etoposide, MTX, plus ActD alternating with cyclophosphamide and vincristine). ${ }^{20-22}$

This study aims to analyze patients with GTN retrospectively in order to determine the clinicopathologic features and treatment outcomes.

\section{PATIENTS and METHODS}

Electronic records and medical files of patients with GTN followed in Zekai Tahir Burak Women's Health Training and Research Hospital between 2011-2018 were analyzed retrospectively. The ethics committee approval was obtained from Zekai Tahir Burak Women's Health Training and Research Hospital Ethics Committee in 25/02/2019 with the decision number 38. Clinicopathological features, chemotherapy regimens, treatment outcomes, surgical histories, and treatment modalities were analyzed. The study included 32 women over 18 years, with a diagnosis of GTN according to the FIGO criteria. ${ }^{8}$ The patients had received at least one line of chemotherapy. Patients with coexistent second malignancy or ones with missing medical records were excluded. Diagnosis of GTN was based on the FIGO criteria which are as follows; a plateau of serum $\beta$ - human chorionic gonadotropin $(\beta$-hCG) level with a $10 \%$ plus or minus on four tests over a period of 3 weeks; $a \geq 10 \%$ increase in serum $\beta$-hCG value for three or more tests over a period of at least 2 weeks; persistence of $\beta$-hCG values for $>6$ months following a molar evacuation; histologic evidence in favour of choriocarcinoma; and the presence of metastatic disease. ${ }^{8}$ 
All patients were staged according to the FIGO staging system prior to therapy. ${ }^{8}$ Thorax and abdomen computerized tomography scans of all patients were performed for staging. Haemogram, liver, kidney, and thyroid function tests were done. Cranial MRI was performed for patients with lung and liver metastasis and ones with symptoms that may be related to brain metastasis.

All patients were assessed according to the FIGO prognostic risk score which comprises age, the outcome of antecedent pregnancy, the interval from antecedant pregnancy, serum $\beta$-hCG level prior to therapy, the largest tumor size, sites and number of metastases, and prior chemotherapy regimen. Patients with risk scores $<7$ were assigned low-risk GTN while $\geq 7$ were classified as high-risk GTN. ${ }^{8}$

Patients with low-risk GTN received single-agent MTX with or without folinic acid (FA) as the firstline treatment. All patients with low-risk GTN received one of two MTX schedules. These were MTX weekly regimen (30 to $50 \mathrm{mg} / \mathrm{m}^{2}$ intramuscular weekly) and MTX-FA eight-day regimen (MTX $1 \mathrm{mg} / \mathrm{kg}$ IV on days 1, 3, 5, and 7, FA $15 \mathrm{mg}$ orally on days $2,4,6$, and 8 given 24 hours after each MTX dose, every 14 days).

MTX resistant patients received ActD (10 to 12 micrograms $/ \mathrm{kg}$ IV push daily for five days, every 14 days) as second-line therapy.

Patients with high-risk GTN were given the combined chemotherapy regimen of EMA-CO (Etoposide $100 \mathrm{mg} / \mathrm{m}^{2}$ IV on days 1 and 2, MTX 100 $\mathrm{mg} / \mathrm{m}^{2} \mathrm{IV}$ bolus followed by $200 \mathrm{mg} / \mathrm{m}^{2} \mathrm{IV}$ over 12 hours on day 1 , ActD $0.5 \mathrm{mg}$ IV bolus on days 1 and 2, FA $15 \mathrm{mg}$ orally every 12 hours for four doses, starting 24 hours after start of MTX, Сyclophosphamide $600 \mathrm{mg} / \mathrm{m}^{2}$ IV on day 8 , Vincristine $1.0 \mathrm{mg} / \mathrm{m}^{2} \mathrm{IV}$ on day 8 , every 14 days) as the first-line therapy. Patients with resistant disease received various chemotherapy regimens such as EMA-EP (Etoposide $100 \mathrm{mg} / \mathrm{m}^{2} \mathrm{IV}$ on days 1, 2 and 8, MTX $100 \mathrm{mg} / \mathrm{m}^{2}$ IV bolus followed by 200 $\mathrm{mg} / \mathrm{m}^{2} \mathrm{IV}$ over 12 hours on day 1 , ActD $0.5 \mathrm{mg}$ IV bolus on days 1 and 2, FA $15 \mathrm{mg}$ orally every 12 hours for four doses, starting 24 hours after start of MTX, cisplatin $60 \mathrm{mg} / \mathrm{m}^{2}$ IV on day 8 , every 14 days), BEP (cisplatin $20 \mathrm{mg} / \mathrm{m}^{2}$ IV on days $1,2,3$, 4 and 5, Etoposide $100 \mathrm{mg} / \mathrm{m}^{2} \mathrm{IV}$ on days $1,2,3$,
4 and 5, Bleomycin $30 \mathrm{mg} \mathrm{IV}$ on days 1,8 and 15 , every 21 days ), TP/TE (Paclitaxel $135 \mathrm{mg} / \mathrm{m}^{2}$ IV on days 1 and 15 , Cisplatin $60 \mathrm{mg} / \mathrm{m}^{2} \mathrm{IV}$ on day 1 , Etoposide $150 \mathrm{mg} / \mathrm{m}^{2} \mathrm{IV}$ on day 15 , every 28 days ), and Pegylated liposomal doxorubicin ( $40 \mathrm{mg} / \mathrm{m}^{2}$ IV on day 1 , every 28 days) in later lines of therapy. Serum $\beta$-hCG levels were monitored at the beginning and weekly during the therapy. Serum $\beta$ -hCG levels were followed monthly for a year after achievement of complete remission (CR). Control examinations were performed every 3 months in 1 st to 2 nd year, every 6 months from 2 nd to 5 th year. In patients with $\mathrm{CR}$, three more cycles of the last regimen were given for consolidation. The treatment outcomes were defined as follows; $\mathrm{CR}$, defined as the condition when quantitative serum $\beta$-hCG level becomes undetectable for three consecutive weeks; and resistant or progressive disease, defined as an increase or a plateau in two consecutive $\beta$-hCG levels over an interval of two weeks or detection of new metastases. ${ }^{23,24}$ Recurrent disease, defined as re-elevation of $\beta$-hCG level after becoming undetectable for three consecutive weeks.

Statistical analyses were performed using the Statistics Package for the Social Sciences SPSS v 11.5 (SPSS Inc., Chicago, IL). While continuous variables were reported as median and range, binary variables were expressed as counts and percentages. Categorical variables were compared by Pearson's chi-square test. A p value $<0.05$ was accepted as statistically significant.

\section{RESULTS}

A total of 32 patients 27 (84.4\%) of whom had lowrisk and five (15.6\%) had high-risk GTN were analyzed. Median follow-up time was 32.1 (3.3-76.9) months. Baseline characteristics of the patients were given in Table 1.

Among the 27 patients with low-risk GTN, 20 received MTX weekly and seven had MTX-FA eight-day regimen as the first-line treatment. Of the 27 patients, 17 (62.9\%) achieved CR. The CR rate was $60 \%(12 / 20)$ in patients receiving MTX weekly and $71.4 \%$ (5/7) in MTX-FA eight-day regimen $(p=0.590)$. The median duration of therapy 


\begin{tabular}{|c|c|}
\hline & $(n=32)$ \\
\hline Age(years), median(range) & $29(18-40)$ \\
\hline Gravida, median(range) & $3(1-7)$ \\
\hline Parity, median(range) & $1(0-6)$ \\
\hline FIGO risk score, median(range) & $3(1-10)$ \\
\hline Interval (months) $\alpha$, median(range) & $1.7(0.16-15.1)$ \\
\hline \multicolumn{2}{|l|}{ Antecedent pregnancy, number (\%) } \\
\hline Mole & $26(81.3)$ \\
\hline Term & $4(12.4)$ \\
\hline Abortion & $2(6.3)$ \\
\hline \multicolumn{2}{|c|}{ Pretreatment serum $\beta$-hCG (mIU/mL), number (\%) } \\
\hline$<10^{3}$ & 7 (21.9) \\
\hline $10^{3}-10^{4}$ & $10(31.3)$ \\
\hline $10^{4}-10^{5}$ & $10(31.3)$ \\
\hline$>10^{5}$ & $5(15.5)$ \\
\hline \multicolumn{2}{|l|}{ FIGO stage, number (\%) } \\
\hline I & $14(43.8)$ \\
\hline$\|$ & $1(3.1)$ \\
\hline III & $16(50)$ \\
\hline IV & $1(3.1)$ \\
\hline \multicolumn{2}{|l|}{ FIGO risk score, number (\%) } \\
\hline $0-6$ & $27(84.4)$ \\
\hline$\geq 7$ & $5(15.6)$ \\
\hline \multicolumn{2}{|l|}{ Site of metastases, number (\%) } \\
\hline Lung & $17(53,1)$ \\
\hline Vagina & $1(3,1)$ \\
\hline Brain & $1(3,1)$ \\
\hline \multicolumn{2}{|l|}{ Largest tumor size, number (\%) } \\
\hline$<3 \mathrm{~cm}$ & $26(81.3)$ \\
\hline 3 to $4 \mathrm{~cm}$ & $4(12.4)$ \\
\hline$\geq 5 \mathrm{~cm}$ & $2(6.3)$ \\
\hline \multicolumn{2}{|c|}{$\begin{array}{l}\alpha=\text { Interval (in months) between end of antecedent pregnan } \\
\text { cy and start of chemotherapy; CT }=\text { Chemotherapy }\end{array}$} \\
\hline
\end{tabular}

to achieve CR was 7 weeks (range 3-22) in patients given MTX weekly and 6 weeks (range 4-10) in patients receiving MTX-FA eight-day regimen $(\mathrm{p}=0.915)$. In patients with low-risk GTN treated with MTX; CR rate was $78.6 \%$ (11/14) in stage 1, and $46.2 \%(6 / 13)$ in stage 2-3. The comparison of MTX weekly and MTX-FA eight-day regimens in the first-line treatment of low-risk GTN was summarized in Table 2.

Of the 10 MTX-resistant patients, nine recieved single-agent ActD as second-line treatment while one patient underwent a second session of dilatation/curettage $(\mathrm{D} / \mathrm{C})$. The patient undergoing $\mathrm{D} / \mathrm{C}$ attained $\mathrm{CR}$ and did not recieve further treatment. Of the nine patients receiving actD, $8(88.8 \%)$ achieved CR. One patient who was resistant to ActD was commenced EMA-CO regimen as the third-line therapy. However, after achievement of $\mathrm{CR}$ with EMA-CO, recurrent disease was detected one month after the end of treatment. The patient achieving CR after hysterectomy was followed without subsequent chemotherapy.

Of the patients with low-risk GTN, recurrent disease ocurred in one patient (3.7\%) and CR was obtained in all patients by means of sequential therapies. At the time of data cut-off, all patients with low-risk GTN are followed with CR.

Of the 5 patients with high-risk GTN, all received first-line EMA-CO regimen. Sixty percent (3/5) attained CR. Of the two patients resistant to EMA$\mathrm{CO}$, one was given second-line $\mathrm{BEP}$ regimen. $\mathrm{CR}$ was achieved with BEP regimen. The other resistant patient recieved EMA-EP and TE/TP regimens respectively. Three fraction (3x10 Gy) Stereotactic body radiation therapy (SBRT) was applied for brain metastasis. This patient is still on pegylated liposomal doxorubicin therapy for resistant disease. At the time of data cut-off, four patients with

\begin{tabular}{|llll|}
\hline \multicolumn{2}{|l|}{ Table 2. Comparison of Methotrexate regimens } & & \\
\hline & MTX Weekly & MTX-FA eight-day & p \\
\hline $\begin{array}{l}\text { The duration of treatment to CR (weeks), } \\
\quad \text { Median (Min-Max) }\end{array}$ & $6(3-22)$ & 0.915 \\
$\begin{array}{l}\text { CR rates, \% } \\
\text { Number of total cycle, } \\
\text { Median (Min-Max) }\end{array}$ & $60(12 / 20)$ & $71,4(5 / 7)$ & 0.590 \\
\hline MTX= Methotrexate, FA= folinic acid, CR= complete remission & $6(3-13)$ & \\
\hline
\end{tabular}


Table 3. Treatment modalities of the patients

Number $(n=32) \%$

First line CT regimen

$\begin{array}{lll}\text { MTX weekly } & 20 & 62.5\end{array}$

MTX-FA eight-day 721.9

EMA-CO $\quad 5 \quad 15.6$

Number of total CT lines

$1 \quad 21 \quad 65.6$

$\begin{array}{lll}2 & 9 & 28.2\end{array}$

$\begin{array}{lll}3 & 1 & 3.1\end{array}$

$\begin{array}{lll}4 & 1 & 3.1\end{array}$

Hysterectomy

$\begin{array}{lll}\text { Yes } & 4 & 12.5\end{array}$

$\begin{array}{lll}\text { No } & 28 & 87.5\end{array}$

Radiotherapy

Yes

1

3.1

No

31

96.9

MTX= Methotrexate; $F A=$ folinic acid $; C T=$ Chemotherapy, EMA-CO= Etoposide, Methotrexate, Actinomicyn D, Cyclophosphamide, Vincristine

high- risk GTN are followed with CR, and one is still on treatment.

When the total number of chemotherapy lines patients received were considered, 21 patients $(65.6 \%)$ received one line, nine patients $(28.2 \%)$ received two lines, one patient $(3.1 \%)$ received three lines, and one patient $(3.1 \%)$ recieved four lines of chemotherapy. Four (12.5\%) patients underwent hysterectomy at various steps of treatment. At the time of data cut off, all patients are alive. Treatment modalities of all patients were summarized in Table 3.

\section{DISCUSSION}

In the current study we aimed to present the treatment outcome of 32 patients with GTN diagnosed according to the FIGO criteria. We achieved a CR rate of $62.9 \%$ with MTX monotherapy in patients with low-risk GTN. A CR rate of $88.8 \%$ was obtained with single-agent Act-D in MTX-resistant patients. Consequently, we acquired CR in all of our low-risk patients with sequential treatments. We obtained a CR rate of $60 \%$ in high-risk GTN patients with first-line EMA-CO regimen. We can conclude that our results are in accordance with the current literature.

MTX and ActD are the most commonly preferred agents in first-line treatment. ${ }^{25,26}$ Although there is no consensus on which agent should be administered as the first-line, MTX is generally preferred since it is available, well tolerated, and cost-effective. ${ }^{16-18,24}$ MTX (with or without FA) has variety of schedules worldwide, whereas there is no evidence-based data to assume one of these schedules as the standard regimen. In a study reporting the experience of The New England Trophoblastic Disease Center on 325 patients with low-risk GTN, 8-day MTX-FA regimen was compared with MTX one-day infusion and FA. Sustained remission rates were reported to be significantly higher with 8-day MTX-FA regimen (84\% vs $62 \%$ ). Although adverse events were more frequent in 8-day MTX-FA regimen, these events were self-limited and recovered without long-term sequelae. ${ }^{27}$ In a study reported by Berkowitz et al. $88 \%$ of patients with low-risk GTN achieved CR with 8-day MTXFA regimen. The CR rate was $90.2 \%$ in stage 1 patients while it was $68 \%$ in patients with low-risk metastatic disease. ${ }^{16}$ In our study, the CR rate with MTX monotherapy was $78.6 \%$ in stage 1 patients while the CR rate was $46.2 \%$ in low-risk metastatic patients. Patients with low-risk GTN receiving 8-day MTX-FA regimen achieved a CR of $71.4 \%$ whereas $60 \%$ of patients on weekly MTX attained $\mathrm{CR}$. This difference was not found to be significant possibly due to low patient number in 8-day MTXFA arm.

The main disadvantage of weekly MTX regimen is the longer duration of treatment needed to attain CR. In a randomized phase III trial conducted by the Gynecologic Oncology Group, treatment periods over 20 weeks were reported in patients recieving weekly MTX. ${ }^{28}$ Similarly, in our study treatment periods up to 25 weeks were present in weekly MTX group. However, median durations of treatment to achive CR were not significantly different between weekly MTX and 8-day MTXFA groups.

Although higher remission rates were reported with ActD, it is generally preferred in MTX resistant patients or ones whom MTX is contraindicated 
due to increased toxicity associated with ActD. ${ }^{14,29-}$ ${ }^{32}$ In a study by Prouvot et al on 103 patients from the French Trophoblastic Disease Reference Center, a CR rate of $75.7 \%$ was achieved with ActD in MTX-failed low-risk GTN. ${ }^{33}$ In our study, a similar CR rate of $88.8 \%$ was achieved with second-line ActD monotherapy in MTX-resistant patients.

Multiple agent chemotherapy is required in the first-line treatment of patients with high risk GTN and the risk of resistance to monotherapy is higher in these patients. ${ }^{19,34}$ The most commonly preferred regimen in first-line treatment of patients with high-risk is EMA-CO yielding CRs of $71-78 \%$ and long-term survival rates of $85-94 \%{ }^{20,34-41} \mathrm{We}$ achieved a CR rate of $60 \%$ with EMA-CO regimen in high-risk patients which is in accordance with the literature.

While brain metastasis is rather scarce in postmolar GTN, central nervous system (CNS) involvement risk reaches up to $20 \%$ in non-molar choriocarcinoma. ${ }^{42}$ Some aouthors suggest using a modified EMA-CO regimen with higher dosage of MTX than the standard dose $\left(1000 \mathrm{mg} / \mathrm{m}^{2}\right)$. They propose that adequate levels of MTX is obtained in cerebrospinal fluid in this way. ${ }^{42-46}$ In a study by Savage et al. on 27 GTN patients with CNS involvement, combination of intrathecal MTX to EMA-CO and EMA-EP (with increased MTX doses up to $1000 \mathrm{mg} / \mathrm{m}^{2}$ ) lead to $85 \%$ long term survival. ${ }^{42}$ In a case series, CR with Pegylated liposomal doxorubicin was reported in heavily pretreated two high-risk GTN patients with brain metastasis. ${ }^{47}$ In our study we had one patient with brain metastasis. She received EMA-CO, EMA-EP, and TP/TE regimens respectively. $\mathrm{CR}$ could not be achived in this patient. SBRT was administered for the brain metastasis. The patient with brain metastasis is still on Pegylated liposomal doxorubicin treatment and she is the only patient followed without CR.

According to a study conducted in New England Trophoblastic Disease Center (NETDC), the rates of recurrent disease was $2.9 \%$ in stage 1 patients, $8.3 \%$ in stage $2,4.2 \%$ in stage 3 , and $9.1 \%$ in stage $4 .^{48}$ In our study, only one patient who had stage 3 disease had recurrence in median follow up time. The recurrence rate was $3.7 \%$ in low-risk GTN patients and $0 \%$ in high-risk patients. The lower recurrence rates in our study may be partially explained by shorter median follow up time of 32 months.

Due to retrospective design of the study, we could not reach some adverse event data of our patients. Therefore, we could not demonstrate adverse events data systematically. We can disclose this as the most important limitation of our study. The strength of our study is providing real-life data of a rare disease. Moreover, our hospital is a tertiary center with experience on gynecologic tumors to which many patients from other provinces are referred. Therefore, our results may potentially reflect the outcome of Turkish patients with GTN.

Consequently, our results showed that GTN is a highly chemo-sensitive disease with excellent prognosis. To commence with MTX is a reasonable option in the treatment of low- risk GTN and all of patients with low risk attained CR with sequential treatments eventually. Furthermore, Actinomycin D is an effective agent in low-risk GTN patients who failed with MTX.

\section{REFERENCES}

1. Sebire NJ, Lindsay I. Current issues in the histopathology of gestational trophoblastic tumors. Fetal Pediatr Pathol 29:3044, 2010.

2. Kajii T, Ohama K. Androgenetic origin of hydatidiform mole. Nature 268: 633-634, 1977.

3. Hertig AT, Mansell $H$. Tumors of the female sex organs. Part 1. Hydatidiform mole and choriocarcinoma. In: Atlas of Tumor Pathology (1st series), Armed Forces Institute of Pathology, Atlas of Tumor Pathology, Washington, DC, Fascicle 33, Section 9, 1956.

4. Ngan S, Seckl MJ. Gestational trophoblastic neoplasia management: An update. Curr Opin Oncol. 19: 486-491, 2007.

5. Seckl MJ, Sebire NJ, Berkowitz RS. Gestational trophoblastic disease. Lancet 376: 717-729, 2010.

6. Brewer JI, Eckman TR, Dolkart RE, et al. Gestational trophoblastic disease. A comparative study of the results of therapy in patients with invasive mole and with choriocarcinoma. Am J Obstet Gynecol 109: 335-340, 1971.

7. Goldstein DP, Berkowitz RS. Current management of gestational trophoblastic neoplasia. Hematol Oncol Clin North Am 26: 111-131, 2012. 
8. FIGO staging for gestational trophoblastic neoplasia 2000. FIGO oncology committee. Int J Gynaecol Obstet 77: 285287, 2002.

9. WHO Scientific Group on Gestational Trophoblastic Diseases \& World Health Organization. (1983). Gestational trophoblastic diseases: report of a WHO scientific group [meeting held in Geneva from 6 to 10 December 1982]. World Health Organization.

10. Lurain JR. Treatment of gestational trophoblastic tumors. Curr Treat Option On 3: 113-124, 2002.

11. Gordon AN, Gershenson DM, Copeland LJ, et al. High-risk metastatic gestational trophoblastic disease: Further stratification into two clinical entities. Gynecol Oncol 34: 54-56, 1989.

12. Mortakis AE, Braga CA. "Poor prognosis" metastatic gestational trophoblastic disease: The prognostic significance of the scoring system in predicting chemotherapy failures. Obstet Gynecol 76: 272-277, 1990.

13. Dubuc-Lissoir J, Sweizig S, Schlaerth JB, et al. Metastatic gestational trophoblastic disease: A comparison of prognostic classification systems. Gynecol Oncol 45: 40-45, 1992.

14. Lawrie TA, Alazzam M, Tidy J, et al. First-line chemotherapy in low-risk gestational trophoblastic neoplasia. Cochrane Database Syst Rev 2016: Cd007102.

15. Lurain JR, Elfstrand EP. Single-agent methotrexate chemotherapy for the treatment of nonmetastatic gestational trophoblastic tumors. Am J Obstet Gynecol 172: 574-579, 1995.

16. Berkowitz RS, Goldstein DP, Bernstein MR. Ten year's experience with methotrexate and folinic acid as primary therapy for gestational trophoblastic disease. Gynecol Oncol 23: 111118, 1986.

17. Berkowitz RS, Goldstein DP, Bernstein MR. Methotrexate infusion and folinic acid in the primary therapy of nonmetastatic gestational trophoblastic tumors. Gynecol Oncol 36: 56-59, 1990.

18. Garrett AP, Garner EO, Goldstein DP, et al. Methotrexate infusion and folinic acid as primary therapy for nonmetastatic and low-risk metastatic gestational trophoblastic tumors. 15 years of experience. J Reprod Med 47: 355-362, 2002.

19. Lurain JR, Schink JC. Importance of salvage therapy in the management of high-risk gestational trophoblastic neoplasia. J Reprod Med 257: 219-224, 2012.

20. Lurain JR, Singh DK, Schink JC. Primary treatment of metastatic high-risk gestational trophoblastic neoplasia with emaco chemotherapy. J Reprod Med 51: 767-772, 2006.

21. Deng L, Zhang J, Wu T, Lawrie TA. Combination chemotherapy for primary treatment of high-risk gestational trophoblastic tumour. Cochrane Database Syst Rev 2013: 31: Cd005196.

22. Kim SJ, Bae SN, et al. Effects of multiagent chemotherapy and independent risk factors in the treatment of high-risk gtt-25 years experiences of kri-trd. Int J Gynaecol Obstet 60 Suppl 1: 85-96, 1998.
23. Golfier $F$, Labrousse $C$, Frappart $L$ et al. [evaluation of treatment relating to gestational trophoblastic tumor registered to the french trophoblastic disease reference center (tdrc) in lyon from 1999 to 2005]. Gynecol Obstet Ferti 35: 205-215, 2007.

24. McNeish IA, Strickland S, Holden L, et al. Low-risk persistent gestational trophoblastic disease: Outcome after initial treatment with low-dose methotrexate and folinic acid from 1992 to 2000. J Clin Oncol 20: 1838-1844, 2002.

25. National comprehensive cancer network guidelines on gestational trophoblastic neoplasia. https://www.nccn.org/ professionals/physician_gls/default.aspx\#gtn. (Access date: 21.06.2019)

26. Ngan HYS, Seckl MJ, Berkowitz RS, et al. Update on the diagnosis and management of gestational trophoblastic disease. Int J Gynaecol Obstet 143 Suppl 2: 79-85, 2018.

27. Maesta I, Nitecki R, Horowitz NS, et al. Effectiveness and toxicity of first-line methotrexate chemotherapy in low-risk postmolar gestational trophoblastic neoplasia: The new england trophoblastic disease center experience. Gynecol Oncol 148: 161-167, 2018.

28. Osborne RJ, Filiaci V, Schink JC, et al. Phase iii trial of weekly methotrexate or pulsed dactinomycin for low-risk gestational trophoblastic neoplasia: A gynecologic oncology group study. J Clin Oncol 29: 825-831, 2011.

29. Lertkhachonsuk AA, Israngura N, Wilailak Sea. Actinomycin d versus methotrexate-folinic acid as the treatment of stage I, low-risk gestational trophoblastic neoplasia: A randomized controlled trial. Int J Gynecol Cancer 19: 985-988, 2009.

30. Yarandi F, Mousavi A, Abbaslu F, et al. Five-day intravascular methotrexate versus biweekly actinomycin-d in the treatment of low-risk gestational trophoblastic neoplasia: A clinical randomized trial. Int J Gynecol Cancer 26: 971-976, 2016.

31. Ross GT, Goldstein DP, Hertz R, et al. Sequential use of methotrexate and actinomycin $\mathrm{d}$ in the treatment of metastatic choriocarcinoma and related trophoblastic diseases in women. Am J Obstet Gynecol 93: 223-229, 1965.

32. Ross GT, Stolbach LL, Hertz R. Actinomycin d in the treatment of methotrexate-resistant trophoblastic disease in women. Cancer Res 22: 1015-1017, 1962.

33. Prouvot C, Golfier F, Massardier J, et al. Efficacy and safety of second-line 5-day dactinomycin in case of methotrexate failure for gestational trophoblastic neoplasia. Int J Gynecol Cancer 28: 1038-1044, 2018.

34. Cagayan MS. High-risk metastatic gestational trophoblastic neoplasia. Primary management with ema-co (etoposide, methotrexate, actinomycin d, cyclophosphamide and vincristine) chemotherapy. J Reprod Med 57: 231-236, 2012.

35. Schink JC, Singh DK, Rademaker AW, et al. Etoposide, methotrexate, actinomycin d, cyclophosphamide, and vincristine for the treatment of metastatic, high-risk gestational trophoblastic disease. Obstet Gynecol 80: 817-820, 1992. 
36. Bolis $\mathrm{G}$, Bonazzi $\mathrm{C}$, Landoni $\mathrm{F}$, et al. Ema/co regimen in highrisk gestational trophoblastic tumor (GTT). Gynecol Oncol 31: 439-444, 1988;

37. Bower M, Newlands ES, Holden L, et al. Ema/co for highrisk gestational trophoblastic tumors: Results from a cohort of 272 patients. J Clin Oncol 15: 2636-2643, 1997.

38. Kim SJ, Bae SN, Kim JH, et al. Risk factors for the prediction of treatment failure in gestational trophoblastic tumors treated with ema/co regimen. Gynecol Oncol 71: 247-253, 1998.

39. Matsui H, Suzuka K, litsuka $Y$, et al. Combination chemotherapy with methotrexate, etoposide, and actinomycin $d$ for high-risk gestational trophoblastic tumors. Gynecol Oncol 78: 28-31, 2000.

40. Escobar PF, Lurain JR, Singh DK, et al.Treatment of high-risk gestational trophoblastic neoplasia with etoposide, methotrexate, actinomycin d, cyclophosphamide, and vincristine chemotherapy. Gynecol Oncol 91: 552-557, 2003.

41. Turan T, Karacay O, Tulunay G, et al. Results with ema/co (etoposide, methotrexate, actinomycin d, cyclophosphamide, vincristine) chemotherapy in gestational trophoblastic neoplasia. Int J Gynecol Cancer 16: 1432-1438, 2006.

42. Savage P, Kelpanides I, Tuthill M, et al. Brain metastases in gestational trophoblast neoplasia: An update on incidence, management and outcome. Gynecol Oncol 137: 73-76, 2015.

43. Newlands ES, Holden L, Seckl MJ, et al. Management of brain metastases in patients with high-risk gestational trophoblastic tumors. J Reprod Med 47: 465-471, 2002.

44. Newlands ES. The management of recurrent and drug-resistant gestational trophoblastic neoplasia (gtn). Best Pract Res Clin Obstet Gynaecol 17: 905-923, 2003.

45. Small W, Jr., Lurain JR, Shetty RM, et al. Gestational trophoblastic disease metastatic to the brain. Radiology 200: 277280, 1996.
46. Rustin GJ, Newlands ES, Begent RH, et al. Weekly alternating etoposide, methotrexate, and actinomycin/vincristine and cyclophosphamide chemotherapy for the treatment of cns metastases of choriocarcinoma. J Clin Oncol 7: 900-903, 1989.

47. Popadiuk C, Power P. Pegylated liposomal doxorubicin is an active agent for chemotherapy-resistant choriocarcinoma: A report of two cases. J Reprod Med 61: 215-218, 2016.

48. Berkowitz RS, Goldstein DP. Current management of gestational trophoblastic diseases. Gynecol Oncol 112: 654-662, 2009.

\section{Correspondence:}

Dr. Veli SUNAR

Saglik Bilimleri Üniversitesi

Dr. Zekai Tahir Burak Kadın Sağlığı

Egitim ve Arastirma Hastanesi

Tibbi Onkoloji Klinigi

Hacettepe Mah, Talatpaşa Blulvari

06230 Samanpazarı, Alındağ

ANKARA / TURKEY

e-mail: velisunar@gmail.com

Tel: (+90-555) 5608024 